\title{
Publisher Correction: p62 - a new metabolic tumour suppressor
}

Ivone Leong

Nature Reviews Endocrinology (2018) https://doi.org/10.1038/s41574-018-0018-0

Published online 24 April 2018

In the original version of the published article, the reference was incorrect. The reference should have read 'Huang, J. et al. Adipocyte p62/SOSTM1 suppresses tumorigenesis through opposite regulations of metabolism in adipose tissue and tumour. Cancer Cell 33, 770-784 (2018).

This has now been corrected in the HTML and PDF version of the article.

https://doi.org/10.1038/s41574-018-0070-9 I Published online 2 August 2018

\section{Publisher Correction: DRP1 links mitochondrial dynamics to the clock}

\section{Ivone Leong}

Nature Reviews Endocrinology (2018) https://doi.org/10.1038/nrendo.2018.32

Published online 09 March 2018

In the original version of the published article, the reference was incorrect. The reference should have read 'Schmitt, K. et al. Circadian control of DRP1 activity regulates mitochondrial dynamics and bioenergetics. Cell Metab. https://doi.org/10.1016/j.cmet.2018.01.011 (2018)'.

https://doi.org/10.1038/s41574-018-0071-8 I Published online 30 July 2018 